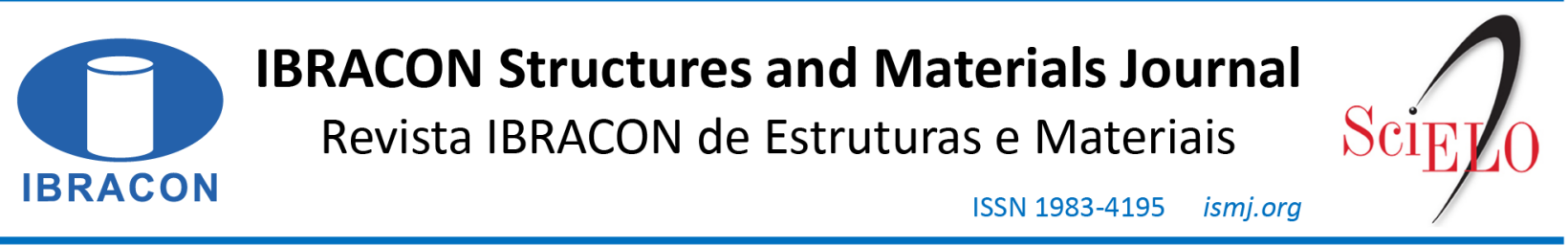

ORIGINAL ARTICLE

\title{
Investigation of the adherence between clay blocks and grouts
}

\author{
Investigação da aderência entre blocos cerâmicos e grautes
}

\author{
Gustavo Sipp ${ }^{\mathrm{a}}$ \\ Guilherme Aris Parsekian ${ }^{\mathrm{a}}$ (D)
}

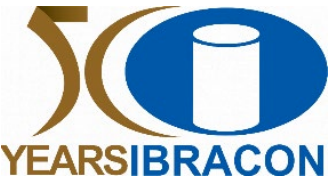

${ }^{\text {a} U n i v e r s i d a d e ~ F e d e r a l ~ d e ~ S a ̃ o ~ C a r l o s ~-~ U F S C a r, ~ D e p a r t a m e n t o ~ d e ~ E n g e n h a r i a ~ C i v i l, ~ S a ̃ o ~ C a r l o s, ~ S a ̃ o ~ P a u l o, ~ B r a s i l ~}$

Received 15 April 2021

Accepted 02 July 2021

\begin{abstract}
This study aims to evaluate the adherence between clay blocks and grouts. For this purpose, pushout and pull-out tests were performed to assess the adherence presented by different combinations of five types of clay blocks and two types of grouts. The results demonstrated that the geometry of the cells of the clay blocks has a preponderant role in their adherence with grout, as the extent of the contact area between grout and block depends on the geometry of the cell. The shrinkage of the grout can cause the formation of cracks at the interface between block and grout, reducing the adherence between the materials. The shrinkage formed inside each type of block can be estimated based on the testing procedure developed in this research and used in conjunction with the geometric characteristics of the cells of the blocks to estimate the maximum load in the push-out tests. The test procedure developed to estimate the percentage of contact area lost due to grouts shrinkage shows to be promising, since its results were used in the equation to estimate the bond strength between blocks and grouts and shown good correlation. However, more study must be done because there are other variables that can affect the results. These results show that it is possible to use different characteristics of blocks and grouts to increase the adherence between these materials and provide a better behavior for reinforced masonry structures. However, it looks like if block types with a grooved hollow cell are used, a bigger contact surface is produced, and a higher bond strength appears to be assured.
\end{abstract}

Keywords: Grout, clay block, adherence, push-out test, pull-out test.

\begin{abstract}
Resumo: Este estudo tem como objetivo avaliar a aderência entre blocos cerâmicos e grautes. Para isso, foram realizados ensaios de push-out e pull-out para avaliar a aderência apresentada por diferentes combinações de cinco tipos de blocos cerâmicos e dois tipos de grautes. Os resultados demonstraram que a geometria da célula dos blocos cerâmicos tem papel preponderante em sua aderência com o graute, pois a extensão da área de contato entre graute e bloco depende da geometria da célula. A retração do graute pode causar a formação de fissuras na interface entre blocos e graute, reduzindo a aderência entre os materiais. A retração formada dentro de cada tipo de bloco pode ser estimada com base no procedimento de ensaio desenvolvido nesta pesquisa e usados em conjunto com as características geométricas das células dos blocos cerâmicos para estimar a carga máxima obtida nos ensaios de push-out. O ensaio desenvolvido para estimar a porcentagem de área de contato perdida devido a retração do graute mostra-se promissor, uma vez que seus resultados foram utilizados na equação para estimar a resistência de união entre blocos e rejuntes e apresentaram boa correlação. No entanto, mais estudos precisam ser feitos porque existem outras variáveis que podem afetar os resultados. Foi demonstrado que é possível utilizar diferentes características de blocos e grautes para aumentar a aderência entre esses materiais e proporcionar um melhor comportamento para estruturas de alvenaria armada. No entanto, conclui-se que se forem usados tipos de bloco com vazado ranhurado, uma superfície de contato maior é produzida e uma aderência parece ser garantida.
\end{abstract}

Palavras-chave: Graute, bloco cerâmico, aderência, ensaio de push-out, ensaio de pull-out.

How to cite: G. Sipp, and G. A. Parsekian, "Investigation of the adherence between clay blocks and grouts," Rev. IBRACON Estrut. Mater., vol. 15, no. 1, e15112, 2022, https://doi.org/10.1590/S1983-41952022000100012

Corresponding author: Gustavo Sipp. E-mail: gsipp@hotmail.com

Financial support: This study was financed by the Associação Nacional da Indústria Cerâmica (ANICER) and by the Coordenação de Aperfeiçoamento de Pessoal de Nível Superior - Brasil (CAPES) - Finance Code 001.

Conflict of interest: Nothing to declare. 


\section{INTRODUCTION}

In masonry structures, grout is often used to improve the mechanical properties of structural members. Grout can be used to fill the holes of the blocks, to enhance the compressive strength of the member, and in the case of reinforced masonry, grout serves as the connecting component between steel bars and blocks allowing tensile strength. The behavior of masonry structures is influenced by the physical and mechanical properties of the materials used in their construction and, also, by the characteristics of these materials in the contact interface. These characteristics have a fundamental role in the distribution of stresses and deformations among the various components that have contact surfaces. The shrinkage of the grout used to fill the blocks can also affect the contact surface influencing their bond capacity.

According to Kingsley et al. [1], due to the porous nature of the clay blocks, they tend to absorb water from the grout, the instant they come into contact. The magnitude of this absorption depends on the properties of block and grout. The result of the migration of water to the block will be the reduction of the water/cement ratio of the grout with a significant reduction in its volume (shrinkage). According to Soric and Tulin [2], to evaluate reinforced masonry two types of bond must be considered. The bond between reinforcement and grout, which is highly influenced by the interaction of the reinforcement transverse ribs with the grout and, the bond between grout and blocks, which is highly influenced by the adhesion developed in the contact interface. Ahmed and Feldman [3] and Kisin [4] found evidence of poor bond between concrete blocks and grout when performing 4-point flexural tests in reinforced masonry. The researchers' objective was to evaluate the behavior of walls using different techniques for lap splicing steel bars. The authors identified that walls on which the steel bars were lab spliced in contact (in the same block hollow cell), the mode of rupture was characterized by the pull-out of the reinforcement. However, for walls where the lapped bars were in adjacent cells of the blocks, the form of rupture was different, forming cracks at the interface between blocks and grouts. The load capacity of the walls with this second rupture mode was lower than that presented by the first one, indicating that a greater adherence between grout and blocks could improve the results.

Push-out tests were carried out by Izquierdo et al. [5] to assess the adherence between concrete and clay blocks to two types of grouts. As a result, the authors identified that the bond between grout and concrete blocks was adequate, as the rupture occurred due to cracking of the block. However, on the tests performed with clay blocks, the rupture mode presented by the specimens was the slippage of the grout, providing a significant reduction in the load capacity of the set. The roughness presented by the concrete blocks was 10 times greater than the roughness presented by the clay blocks. The bond strength identified by the authors for the clay blocks were 0.16 and 0.19 $\mathrm{MPa}$, for the use of grout with 14 and $30 \mathrm{MPa}$ of compressive strength, respectively. The authors identified an increase in the bond strength obtained for the clay blocks when the compressive strength of the filling material is greater.

Thamboo et al. [6] evaluated the influence of the surface roughness of concrete blocks on the bond strength with polymer cement mortars. According to the authors, blocks with smooth surfaces presented higher bond strength than blocks with rough surfaces. Pereira de Oliveira [7] reports a study to evaluate the effects of four different grout mixtures on the bond strength with one concrete block type. The mixtures had different levels of water/cement ratio (w/c) and specific area of the aggregates. The results shown that the increase in the w/c ratio decreased the bond strength of the grout/block interface. The increase in the specific area of the aggregate promoted an increase in the bond strength to a certain point and then it decreased. The author recommended to use the bond strength as a criterion to choose the grout for masonry, as well as its compressive strength. Pereira de Oliveira [8] investigated the influence of the bond strength of different grout mixtures on the compressive strength of masonry prisms. The author identified an increase in the compressive strength of prisms with an increase in the bond strength of the grout used. This shows the importance of evaluating this behavior in masonry, not only for reinforced masonry. The push-out test is also reported in Guarnieri et al. [9], to assess the influence of the compressive strength of clay blocks and its holes' geometric shapes on the bond strength with grout. The compressive strength of the grout was $30 \mathrm{MPa}$. The bond strength obtained was 1.73, 1.42, 2.93 and $2.64 \mathrm{MPa}$, for the blocks of 7, 10, 15 and $18 \mathrm{MPa}$ of compressive strength, respectively. Results indicated that there is a tendency to increase the bond strength of the material as the compressive strength of the blocks increases. The predominant mode of rupture was the failure of the fired clay blocks, indicating that the bond strength of the set was superior to the blocks' mechanical capacity. Because the form of rupture identified in the tests was the cracking of the clay blocks, it makes sense to expect an increase on the bond strength for blocks with higher compressive strength, since they were the weak link on the test.

In addition to the push-out test, another technique that has been used to assess the adherence between the elements of reinforced masonry is the pull-out test. This test consists of connecting a steel bar in a masonry element, inside the 
holes of the blocks using grout. After curing the grout, a force is applied to pull-out the steel bar from the interior of the masonry, allowing to evaluate the adherence in the set. The maximum force in the test is divided by the crosssection area of the rebar, obtaining the maximum stress supported by the set. This stress is usually compared to the yield capacity of the steel. Usually, the pull-out test is used to verify the bond between the reinforcement and grout, however, Kisin [4] suggests that this test can also be used to measure the adherence of the rebar to the whole set, including the grout and the blocks that encases the grout. Izquierdo [10] states that the pull-out test evaluates the performance of the block/grout/reinforcement interfaces, as it exerts a force on all the materials in the set. Biggs [11] points out that the failure during the pull-out test will occur at the weakest connection within the set. This may be in the block/grout interface or in the grout/reinforcement interface. According to Biggs [11] there is three different forms of rupture on this test: 1) cracking of the block and its filling material; 2) cracking of the block and sliding of the filling material; and 3) rupture of the filling material around the reinforcement and slippage of the rebar.

Biggs [11] reports reinforcement bars pull-out tests in concrete block masonry, using fine-aggregate grout ("fine grout" according to ASTM C 476 [12]). The failure load for grout samples was higher than the yield strength load of the reinforcement. Soric and Tulim [13] carried out pull-out tests on masonry specimens built with concrete blocks and clay blocks. Reinforcement bars with 13 and $22 \mathrm{~mm}$ of diameter were used in the tests. The authors observed a similar behavior for specimens made with concrete and clay blocks when $13 \mathrm{~mm}$ bars were used. For specimens made with clay blocks and $22 \mathrm{~mm}$ bars, an increase in slip was observed at $25 \%$ of the yielding load, while for the specimens made with concrete units, they showed a slip at $50 \%$ of the yielding load. The diameter of the bar, the quality of the grout and the thickness of the masonry are decisive factors for reinforced masonry structures.

Izquierdo et al. [5] carried out pull-out tests to assess the adherence between clay and concrete blocks to the grouts, to complement the results obtained in the push-out tests. As in the push-out tests, the pull-out tests showed good adherence for the grouts when using concrete blocks, making it possible to reach loads higher than the reinforcement yielding capacity. On the other hand, for the tests performed with clay blocks, the slippage of the grout from the interior of the blocks was identified, causing the rupture of the set with loads below steel yielding capacity. The pull-out test allows to complement the results obtained in the push-out tests, with results closer to the behavior of actual masonry structures. The pull-out test allows to consider the influence of the imperfections of the vertical laying of the blocks between the courses, which create indents that can contribute to inhibit the slippage of the filling material and increase the adherence at the interface. This same effect can also be obtained by changing the geometry of the cells of the blocks. A mechanism to hinder the grout slippage can be created when protrusions or indents in the hollow cells of the blocks do not match in position at each laying course.

\subsection{Objectives}

This article aims to evaluate the adherence behavior between different types of fired clay blocks and grouts. Pushout and pull-out tests were performed to assess the adherence among different combinations of blocks and grouts. The hollow cells of the blocks have different geometric shapes, eventually incorporating protrusions and grooves inside the hollow in the contact face. From the results it was possible to assess the behavior of the block-grout interface and to conclude which is the best geometric shape for the block hollow. In addition, an equation was proposed to estimate the bond strength of each combination of block and grout, taken in to account the influence of the geometric shape of the cells of the blocks and the shrinkage of the grout.

\section{MATERIALS AND METHODS}

Five types of fired clay blocks and two types of grouts were tested. The grouts came from the same manufacturer in bags and were used without the addition of coarse aggregates, with nominal compressive strength of $15 \mathrm{MPa}$ (G15) and $30 \mathrm{MPa}(\mathrm{G} 30)$. The amount of water used was enough to promote a consistency of $(250 \pm 20 \mathrm{~mm})$ in the slump test. The five types of blocks used in this research were manufactured by the same company. The dimensions of all the blocks were $140 \times 390 \times 190 \mathrm{~mm}$, respectively, width, length, and height. The blocks differed mainly by their mechanical properties, geometries of the holes and the fact that some had a solid faceshell while others had a perforated faceshell.

Usually, the blocks have a smooth surface inside the holes. However, blocks with protrusions and grooves inside the hollow of the cells surface were produced for testing. To differentiate between the types of blocks, the blocks with a solid (massive) faceshell are called BM, while blocks with a perforated (voided) faceshell are called BV. These abbreviations are followed by a number that indicates the number of indentations present in one of the cells of the block. The different types of blocks used in this research and their nomenclature are shown in Figure 1. 


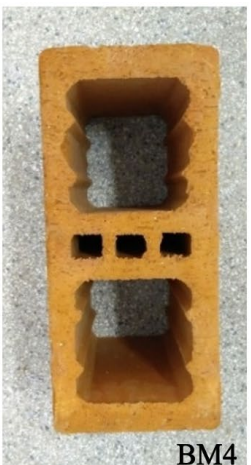

a)

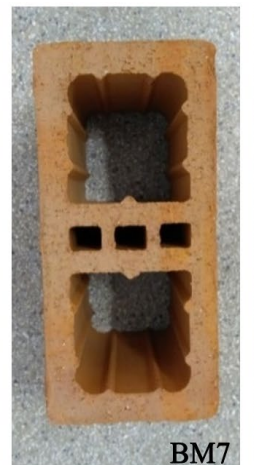

b)

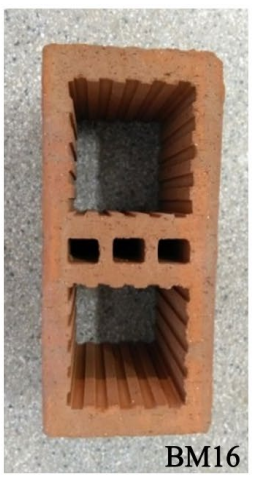

c)

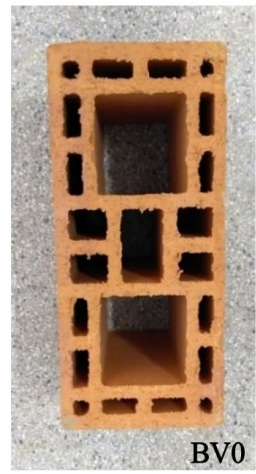

d)

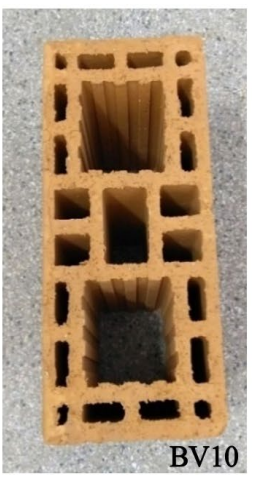

e)

Figure 1. Types of fired clay blocks.

As can be seen in Figure 1, block types BM4, BM7, and BM16 have solid (massive) faceshell. Block types BV0 and BV10 have a perforated (voided) faceshell. In block types BM16 and BV10, the internal surfaces of the cells are grooved to increase the contact area between block and grout. Block types BM4 and BM7 have few indentations in the internal surface of the cell. The block type BV0 is the only one that has smooth surfaces inside the hole. In block type BM7 the indentation in the web face will not match vertically when the block is laid into a running bond pattern, thus creating a kind of a vertical shear key between the grout and block.

\subsection{First phase - Materials characterization}

Physical and mechanical properties of all materials used in the research were determined. The main properties evaluated for the blocks were compressive strength and water absorption. These tests were carried out according to NBR 15270-2 [14] standard procedure, using 13 blocks for measuring compressive strength and six for the determination of water absorption of the blocks. The internal average roughness of each type of block was also measured, using the same equipment as described by Izquierdo [9]. For this test, 6 specimens of each type of block were cut from the faceshell of the blocks. More information can be seen in the Figure 2. Figure 2a shows the cut of a specimen. Figure $2 \mathrm{~b}$ shows the places were specimens were cut in the blocks. Figure $2 \mathrm{c}$ shows the equipment used in the test.

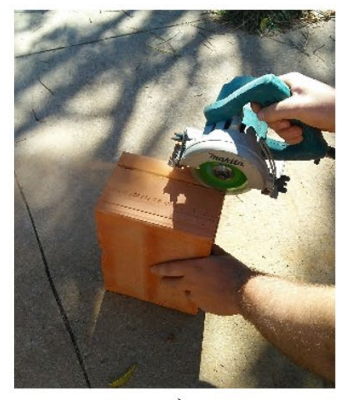

a)

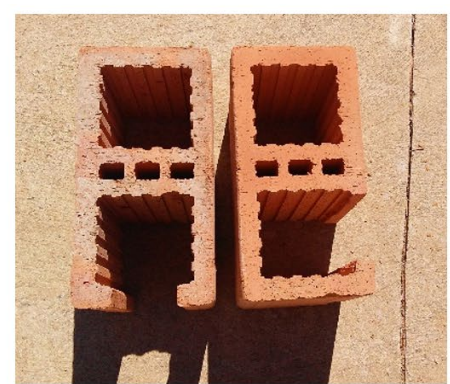

b)

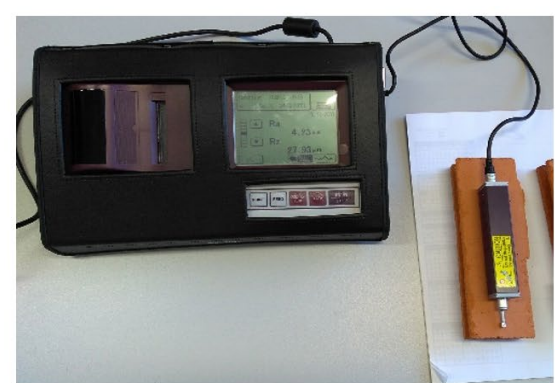

c)

Figure 2. Scheme of roughness test.

The internal dimensions of the cells of the blocks were also measured to determine which type of block provided the largest contact area with grout, and what is the contribution of the indentations to increase the internal surface area of the cells. This geometric characteristic is especially important to understand the intensity of the shear stresses that block-grout interface can tolerate, especially in the push-out test. The main tests used to characterize the grout were compressive strength, tensile strength, elastic modulus, and water absorption. All these tests were performed with six cylindrical specimens $(100 \times 200 \mathrm{~mm})$, following, respectively, the procedures presented in the NBR 5739 [15], NBR 7222 [16], NBR 8522 [17] and NBR 9778 [18] standard codes. 


\subsection{Second phase - Push-out test}

The push-out test was used to determine the bond strength of the contact interface between each type of block and grout, to verify which properties of the materials analyzed in the first phase can affect the bond strength. The push-out specimen consisted of one single clay block with only one of the cells filled with grout. The grout was poured and compacted into the block cell until it protruded $30 \mathrm{~mm}$ out from the top of the block. The test consists of applying a force to remove the grout from the interior of the block. The specimen was positioned over a steel plate with a rectangular window cut. The dimensions of the window matched the overall dimension of the hollow cell of the block. The steel plate can support only the block, allowing the grout to move freely through the window. A displacement-controlled load was applied, at a $1 \mathrm{~mm} /$ minute rate, to the protruding grout surface to expel it from the interior of the block.

The bond strength and the contact area are obtained, respectively, with Equation 1 and Equation 2:

A.S. $=\frac{\text { Fmax }}{\text { C.A. }}$

C.A. $=P \times H$

where $A . S .=$ bond strength $(\mathrm{MPa}) ;$ Fmax. $=$ maximum force during the push-out test $(\mathrm{N}) ; C . A .=$ contact area between block and grout $\left(\mathrm{mm}^{2}\right) ; P=$ perimeter of the hole of the block; and $H=$ height of the block.

The test procedure is illustrated in Figure 3. Figure 3a shows the compaction of the grout. Figure $3 \mathrm{~b}$ shows the steel plate used to support the block. Figure $3 \mathrm{c}$ shows the set ready for test. The compaction of the grout began with the moistening of the interior of the blocks. Later, grout was added inside the block and 25 strokes were applied with a metal rod. After this step, more grout was added and, approximately 5 minutes later, another 25 strokes were applied to compact the grout. This same procedure was applied to all tests that use grout to fill the blocks.

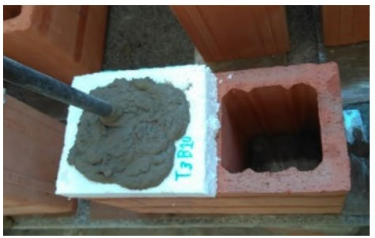

a)

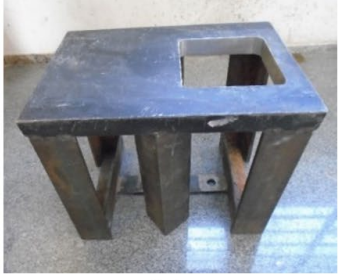

b)

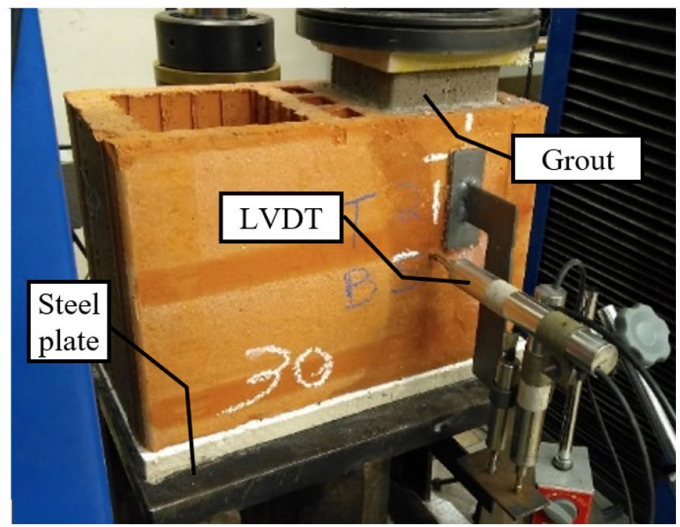

c)

Figure 3. Scheme of push-out test.

For each combination of block and grout type, six specimens were tested. Considering five types of clay blocks and two types of grouts, a total of 60 specimens were tested. The slip of the grout was measured using displacement transducers placed at the block faceshell and connected to the bottom of the grout. 


\subsection{Third phase - Pull-out test}

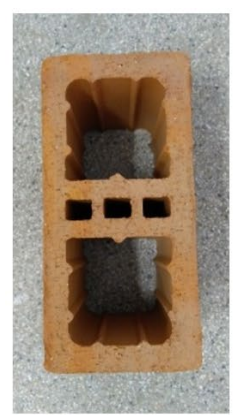

a)

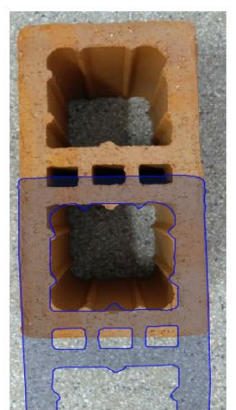

b)

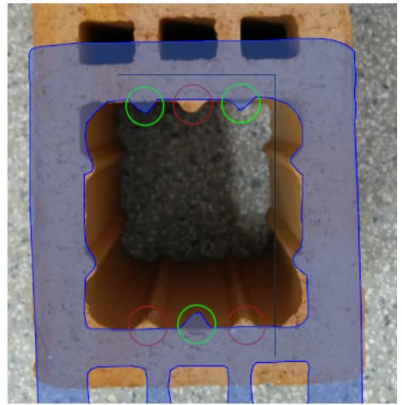

c)

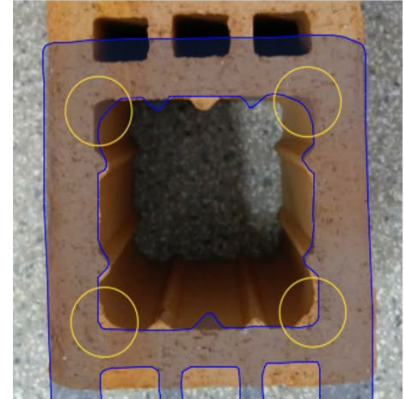

d)

Figure 4. Indentations on the internal surface of the cells (block type BM7).

For this test three types of blocks were used. The BM16 and BV10 types were chosen because they presented the highest bond strength values on the push-out test, among the solid and perforated faceshell blocks, respectively. Additionally, the BM7 type of block was also tested to verify if the presence of the shear keys showed in Figure 4 can contribute to improve adherence of the set, in comparison with the results obtained from push-out tests. Figure 5a shows how load was applied. Figure $5 \mathrm{~b}$ illustrates the scheme assay used for pull-out test and a specimen used. The specimen used in this test was a wall with five-course high and 1.5 blocks wide with blocks laid in a running bond pattern. In the central hole of these walls, a steel bar was embedded in grout to perform the pull-out test after curing. The rebar used in all specimens have a diameter of $16 \mathrm{~mm}$ made from steel CA-50 by the manufacturer ArcelorMittal.

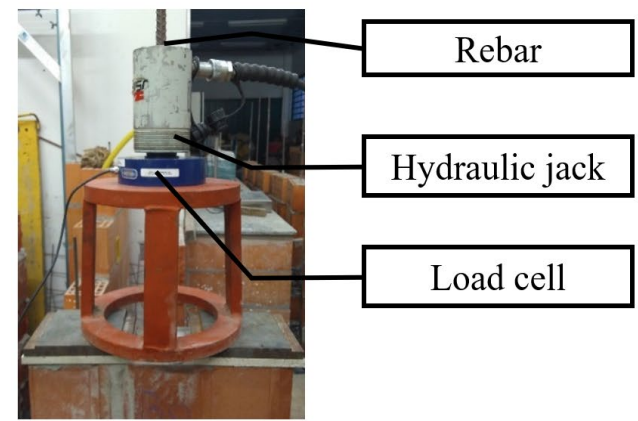

a)
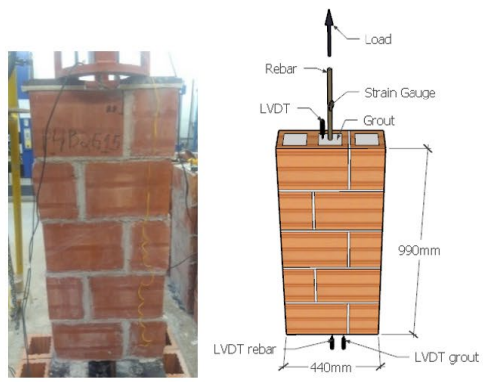

b)

Figure 5. Scheme assay of pull-out test.

The $16 \mathrm{~mm}$ bars were chosen because this is the largest diameter that can be used for block types BV0 and BV10, which have a hollow cross-sectional area of $70 \mathrm{~cm}^{2}$. According to NBR 16868-1 [19], the reinforcement area cannot be greater than $8 \%$ of the grout area, considering the lap splice of the bars. The basic anchorage length for CA-50 16-mm reinforcement according to NBR 6118 [20] is 716 and $519 \mathrm{~mm}$, respectively for grout G15 and G30, smaller than the height of the specimen. For each type of block six walls were built. In three of these walls, reinforcement was embedded in G15 grout, while in the other three walls the reinforcement was embedded in G30 grout. The two other (unreinforced) hollows of each one of the six walls were filled with G30 grout. As can be seen in Figure 5 a strain gauge was used to verify if the reinforcement bar achieves its yield capacity. Two LVDT were used to measure the slippage of the grout on the top and on the bottom of the specimen. Another LVDT was also used on the rebar on the bottom of the specimen to verify the slippage of the rebar. The load was applied on the rebar through a hydraulic jack with a capacity of $20 \mathrm{tf}$ and the load was measured with the load cell with the same capacity. 


\subsection{Fourth phase - Investigations of the grouts' shrinkage}

While the specimens earmarked for the push-out tests were curing, it was noticed that, in some cases, the grout showed signs of shrinkage inside the block. In these cases, a narrow gap appeared at the block-grout interface (Figure 6). Block types BM4 and BM7 presented similar behavior. There were light signals of gap formation in some places of the interface block/grout for the G15 grout and a little more accentuated signals with the G30 grout, outlining almost the entire block/grout interface. The BM16 type of block showed signs of gap formation at some small portions of the interface with the use of grout G15 and at slightly larger portions with grout G30. For the BV0 type of block, some signs of gap formation were observed in some spots of the interface with the G15 grout. For the G30 grout, signs of gap were observed also at some spots, perhaps a little larger than with the G15 grout. For block type BV10, very few signs were observed in small spots of some blocks with grout G15. For the grout G30 the signs seemed to be like the ones find for G15 grout. Thus, it became necessary to investigate the extent of the shrinkage of the two types of grouts and its impact on the bond with the different types of blocks. The shrinkage of the grout was assessed by monitoring the dimensional variation of grout prisms for 28 days as prescribed in NBR 15261 [19].

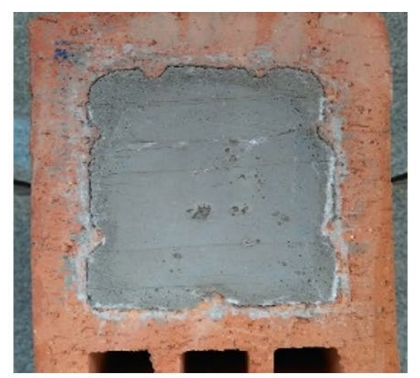

a)

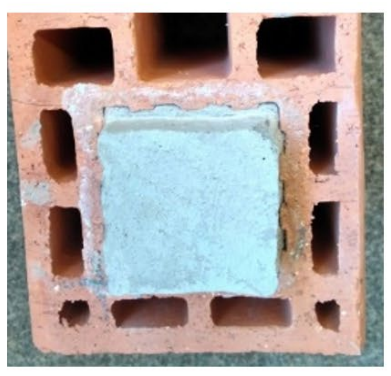

b)

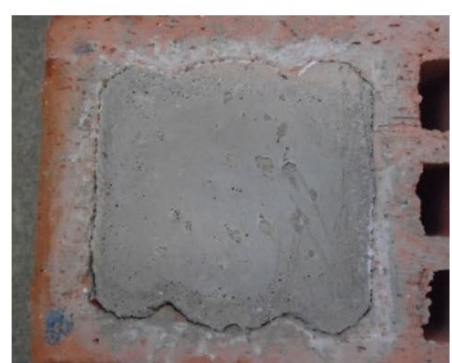

c)

Figure 6. Signs of shrinkage of the grout.

To assess the impact of the grout shrinkage on the interface between blocks and grouts, an alternative procedure was developed. Two blocks of each of the five types were assessed. Each block had one hole filled with grout G15 and other with grout G30. In total, ten blocks were assessed on this testing. After 28 days of grout curing, the blocks were cut in half of its height and the internal surfaces were photographed. The images were digitally incorporated into a CAD program allowing to measure the length of the cracks formed inside the grout and in the block-grout interface. These same images were also used to determine the length of the perimeter of the cell of each type of block used in the procedure. It is possible to calculate the percentage of cracks formed inside the grout or at the interface block/grout, dividing the length of cracks measured by the length of the perimeter of the cell of block.

The percentage of cracks formed at the interface block/grout can be considered as percentage of the contact area lost due to the shrinkage of the grout in certain type of block. This percentage will allow to evaluate which combination of block and grout forms the highest value of cracks and the higher reduction in the contact area due to shrinkage. In Figure 7 different images show the shrinkage in the different combinations of block and grout types: Figure 7a (BV0 and G15), Figure 7b (BV0 and G30), Figure 7c (BM16 and G15) and Figure 7d (BM16 and G30).

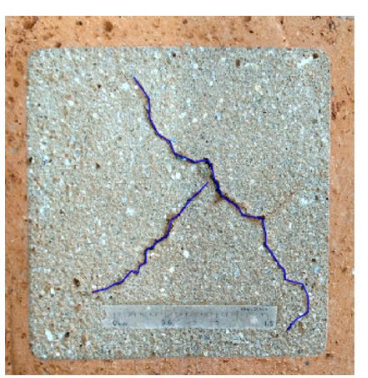

a)

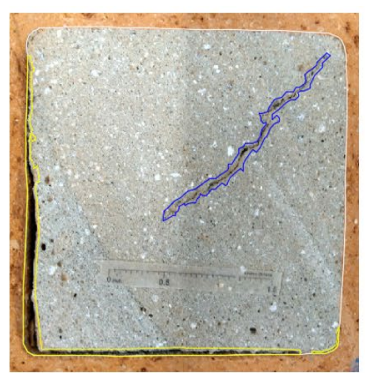

b)

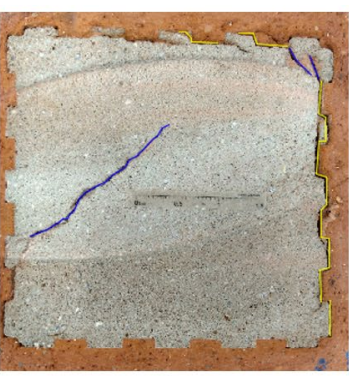

c)

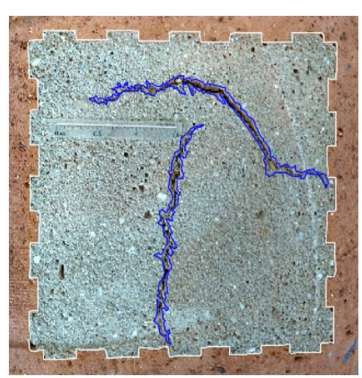

d)

Figure 7. Estimating the effects of shrinkage inside the specimens. 


\section{RESULTS AND DISCUSSION}

\subsection{First phase - Materials characterization}

The geometric properties presented by the different types of clay blocks are shown in Table 1. Values between brackets are the coefficient of variation of the sample.

Table 1. Geometric characteristics of the blocks.

\begin{tabular}{ccccccc}
\hline \multirow{2}{*}{ Type of block $\begin{array}{c}\text { Blocks' gross } \\
\text { area }\left(\mathbf{c m}^{2}\right)\end{array}$} & $\begin{array}{c}\text { Blocks' net } \\
\text { area }\left(\mathbf{c m}^{2}\right)\end{array}$ & & \multicolumn{2}{c}{ Characteristics of the holes of the blocks } \\
\cline { 5 - 7 } & & & Perimeter $(\mathbf{c m})$ & $\begin{array}{c}\text { Cross section } \\
\left(\mathbf{c m}^{2}\right)\end{array}$ & $\begin{array}{c}\text { Smooth contact } \\
\text { area }\left(\mathbf{c m}^{2}\right)\end{array}$ & $\begin{array}{c}\text { Total contact } \\
\left.\mathbf{a r e a}_{(\mathbf{c m}} \mathbf{)}\right)\end{array}$ \\
\hline BM4 & $407(1.2 \%)$ & $201(1.2 \%)$ & $38.7(0.6 \%)$ & $91.8(1.3 \%)$ & $688(1.2 \%)$ & $725(1.1 \%)$ \\
\hline BM7 & $411(0.4 \%)$ & $209(0.3 \%)$ & $37.2(0.3 \%)$ & $89.2(0.5 \%)$ & $652(0.6 \%)$ & $699(0.6 \%)$ \\
\hline BM16 & $400(0.8 \%)$ & $197(0.9 \%)$ & $47.9(0.2 \%)$ & $91.5(0.6 \%)$ & $737(0.7 \%)$ & $899(0.6 \%)$ \\
\hline BV0 & $404(0.5 \%)$ & $180(0.3 \%)$ & $29.1(0.3 \%)$ & $52.9(0.5 \%)$ & $547(0.5 \%)$ & $547(0.5 \%)$ \\
\hline BV10 & $407(0.3 \%)$ & $184(0.2 \%)$ & $33.6(0.2 \%)$ & $51.6(0.6 \%)$ & $561(0.4 \%)$ & $638(0.4 \%)$ \\
\hline
\end{tabular}

The smooth contact area of the blocks presents the contact area without considering the contribution of the indentations on the inside of the cells of the blocks. This contact area varies mainly due to the overall dimensions of the holes in each type of block. The total contact area considers the sum of the smooth area plus the area added by the indentations inside the holes of the blocks. Comparing the two contact areas shown in Table 1, contact area increases of 5, 7, 22, 0 and $14 \%$ resulted from the presence of the indentations, respectively for block types BM4, BM7, BM16, BV0, and BV10. The contact area of the block type BV0 did not show an increase in the total contact area, as it is the only one that has a cell with a smooth internal surface (without indentations). The largest contact area among the massive faceshell blocks was observed in BM16 while the largest contact area among the voided faceshell blocks was in BV10. Therefore, the two blocks with the most irregular (grooved) surfaces were those with the largest contact area. In addition to the geometric properties, water absorption, roughness and compressive strength of the clay blocks can influence the behavior of the adherence between blocks and grouts. The results of these properties can be seen in Table 2.

Table 2. Properties of the blocks.

\begin{tabular}{cccccc}
\hline $\begin{array}{c}\text { Block } \\
\text { Type }\end{array}$ & $\begin{array}{c}\text { Water absorption } \\
(\%)\end{array}$ & $\begin{array}{c}\text { Vertical roughness } \\
(\boldsymbol{\mu m})\end{array}$ & $\begin{array}{c}\text { Characteristic } \\
\text { compressive } \\
\text { strength }(\mathbf{M P a})\end{array}$ & $\begin{array}{c}\text { Avg. compressive } \\
\text { strength (MPa)* }\end{array}$ & $\begin{array}{c}\text { Avg. compressive } \\
\text { strength }(\mathbf{M P a})\end{array}$ \\
\hline BM4 & $12.2(6.9 \%)$ & $8.67(26.6 \%)$ & 20.48 & $27.8(13.4 \%)$ & $56.0(13.4 \%)$ \\
\hline BM7 & $13.2(3.7 \%)$ & $6.90(25.1 \%)$ & 16.82 & $19.7(11.2 \%)$ & $38.6(11.2 \%)$ \\
\hline BM16 & $11.2(4.9 \%)$ & $8.39(37.7 \%)$ & 16.76 & $18.9(8.8 \%)$ & $38.4(8.8 \%)$ \\
\hline BV0 & $12.8(3.3 \%)$ & $8.09(28.4 \%)$ & 13.31 & $17.2(11.3 \%)$ & $38.6(11.3 \%)$ \\
\hline BV10 & $13.9(2.1 \%)$ & $7.46(37.6 \%)$ & 12.12 & $13.4(7.2 \%)$ & $29.7(7.2 \%)$ \\
\hline
\end{tabular}

$(*)$ Compressive strength considering the gross area of the block. $(* *)$ Compressive strength Considering the net area of the block.

As can be seen in Table 2, the water absorption and roughness presented by the different types of blocks are not quite different and should not exert a significant influence on the bond between the materials. The characteristic compressive strength shown by voided faceshell blocks is lower than that presented by massive faceshell blocks. The characteristic compressive strength presented by blocks type BM7 and BM16 are similar, as are those presented by blocks BV0 and BV10, which makes easier the verification of the influence of geometry on the bond between blocks and grouts. However, for the case of average compressive strength in the net area, the block type BV0 presented a result considerably higher than the BV10, which could influence the result of the adherence. Among all types of blocks, the one with the highest resistance was the BM4 type, which has $56 \mathrm{MPa}$ of compressive strength (net area). The block type BV10 has the lowest compressive strength values. Results of the grout characterization tests can be seen in Table 3 . The water/grout (anhydrous) ratio used to obtain the desired consistency at this phase was approximately 0.13 and 0.16 , respectively, for G15 and G30 type of grout. The modulus of elasticity presented by the two materials are similar because the grout used in this study had 
no coarse aggregate which would have increased the modulus for both types of grouts. The use of grout without the presence of coarse aggregates can facilitate the filling of the indentations of the cells of the blocks.

Table 3. Properties of the grouts.

\begin{tabular}{cccc}
\hline Type of grout & $\begin{array}{c}\text { Avg. Compressive strength } \\
\text { (MPa) }\end{array}$ & $\begin{array}{c}\text { Avg. Modulus of elasticity } \\
\text { (GPa) }\end{array}$ & $\begin{array}{c}\text { Avg. Tensile strength } \\
\text { (MPa) }\end{array}$ \\
\hline G15 & $20.3(3.2 \%)$ & $21.9(2.3 \%)$ & $2.2(8.7 \%)$ \\
\hline G30 & $33.6(4.1 \%)$ & $23.3(1.8 \%)$ & $3.7(7.3 \%)$ \\
\hline
\end{tabular}

\subsection{Second phase - Push-out test}

The average maximum bond strength supported by each combination of block and grout type is presented in Table 4. The bond strength obtained with the use of $30 \mathrm{MPa}$ grout was lower than that obtained with $15 \mathrm{MPa}$ grout for all types of blocks. The bond strength in case of $30 \mathrm{MPa}$ grout was lower by approximately $63 \%$ for block BM4, 82\% for block BM7, 21\% for block BM16, 44\% for block BV0 and 1\% for block BV10. This finding of lesser bond strength of the filling material with greater compressive strength differs from the findings of Izquierdo et al [5] and Biggs [11]. In a similar situation, they observed higher adherence values for the filling materials with higher compressive strength. The difference in the results obtained between the grouts G15 and G30, considering the same type of block, was smaller for the BM16 type of block, among the massive faceshell blocks and for BV10 among the voided faceshell blocks. These two types of blocks have the largest number of indentations inside the cells. This indicates that the presence of distinct geometries and a greater number of indentations contributes to a greater adherence between block and grout.

Among the massive and voided faceshell types of blocks, the geometric characteristics of the cells of the block types BM16 and BV10 provided the largest contact areas, respectively. The reduction in the bond strength observed for the block type BV10 with the use of $30 \mathrm{MPa}$ grout was close to nil, perhaps due to the smaller orifice volume of this type of block as compared to BM16 block. The bond strengths of blocks BM7 and BM16 were different when the same type of grout was used. As these blocks displayed similar compressive strength, the distinct geometries of their cells and their distinct contact areas contributed to the difference in the results. The bond strength provided by BM16 was 24 and $83 \%$ higher than that provided by BM7, with the use of grouts G15 and G30, respectively. From the analysis of the bond results of these two types of blocks, the more irregular geometry of the cell of the blocks BM16, with higher number of protrusions, contributed to increase the adherence between the materials. This is even more evident with the results obtained with the grout G30 that caused a reduction in the adherence for all types of blocks.

Table 4. Results of the push-out test.

\begin{tabular}{|c|c|c|c|c|c|c|}
\hline Type of block & Type of grout & $\begin{array}{l}\text { Avg. maximum } \\
\quad \operatorname{load}(k N)\end{array}$ & $\begin{array}{l}\text { Avg. contact } \\
\text { area }\left(\mathrm{cm}^{2}\right)\end{array}$ & $\begin{array}{c}\text { Avg. bond } \\
\text { strength (MPa) }\end{array}$ & S. D. (MPa) & C. V. $(\%)$ \\
\hline \multirow{2}{*}{ BM4 } & G15 & 72.9 & 725 & 1.01 & 0.27 & 26.5 \\
\hline & G30 & 26.6 & 724 & 0.37 & 0.23 & 61.3 \\
\hline \multirow{2}{*}{ BM7 } & G15 & 95.8 & 701 & 1.37 & 0.26 & 19.3 \\
\hline & G30 & 16.7 & 698 & 0.24 & 0.07 & 27.3 \\
\hline \multirow{2}{*}{ BM16 } & G15 & 161.0 & 899 & 1.80 & 0.17 & 9.2 \\
\hline & G30 & 128.8 & 899 & 1.43 & 0.19 & 13.3 \\
\hline \multirow{2}{*}{ BV0 } & G15 & 85.0 & 546 & 1.56 & 0.19 & 12.1 \\
\hline & G30 & 48.3 & 548 & 0.88 & 0.19 & 21.5 \\
\hline \multirow{2}{*}{ BV10 } & G15 & 96.6 & 637 & 1.52 & 0.04 & 2.5 \\
\hline & G30 & 96.5 & 638 & 1.51 & 0.18 & 11.7 \\
\hline
\end{tabular}

Block types BV0 and BV10 also presented similar characteristic compressive strength and a very distinct geometry of the cells. However, despite the geometric differences between these types of blocks, the push-out 
test results were equivalents when $15 \mathrm{MPa}$ grout was used. On the other hand, when G30 grout was used, the bond strength obtained with block BV10 was $42 \%$ higher than that obtained with BV0, which has a smooth internal surface. Thus, in the case of $30 \mathrm{MPa}$ grout, the increase in the contact area provided by the BV10 type of block caused a significant increase in the bond strength, indicating the advantage of using a grooved geometry to improve the bond strength. The mode of rupture presented by the specimens on the push-out tests was in the greater part characterized by the failure of the block and sometimes also of the grout. Samples made with grout G15 were more likely to exhibit rupture of the block and grout. Samples made with grout G30 were more likely to exhibit rupture only of the block. The slippage of the grout was identified only for the combination of grout G30 with block types BM7 and BM4. The BM7 specimens after push-out test are shown in Figure 8a for the use of G15 grout and in Figure 8b for G30 grout. As can be seen, the use of grout G15 presented the rupture of the block and the use of grout G30 produced the slippage of the grout.
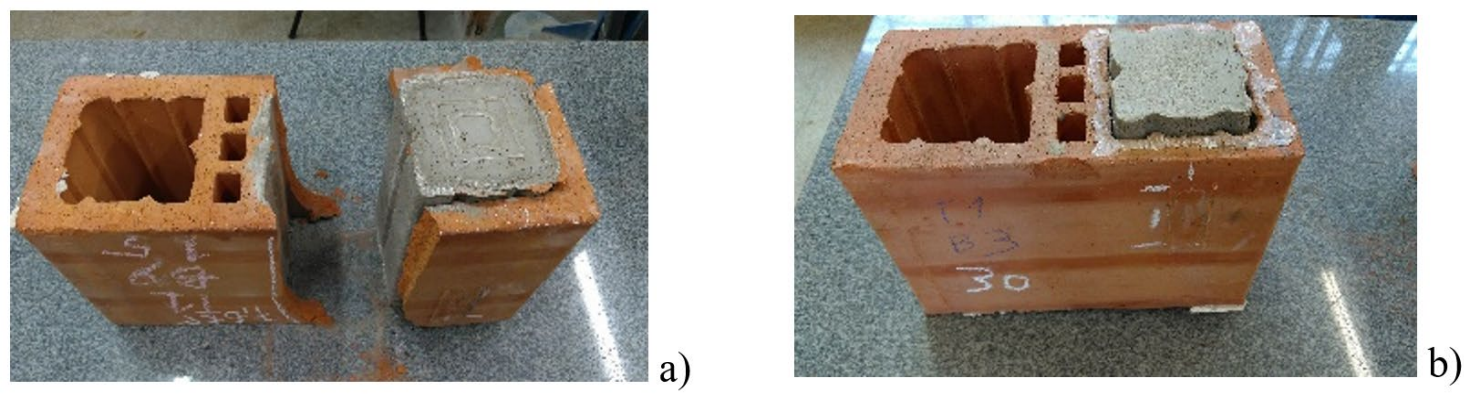

Figure 8. BM7 specimens after push-out test.
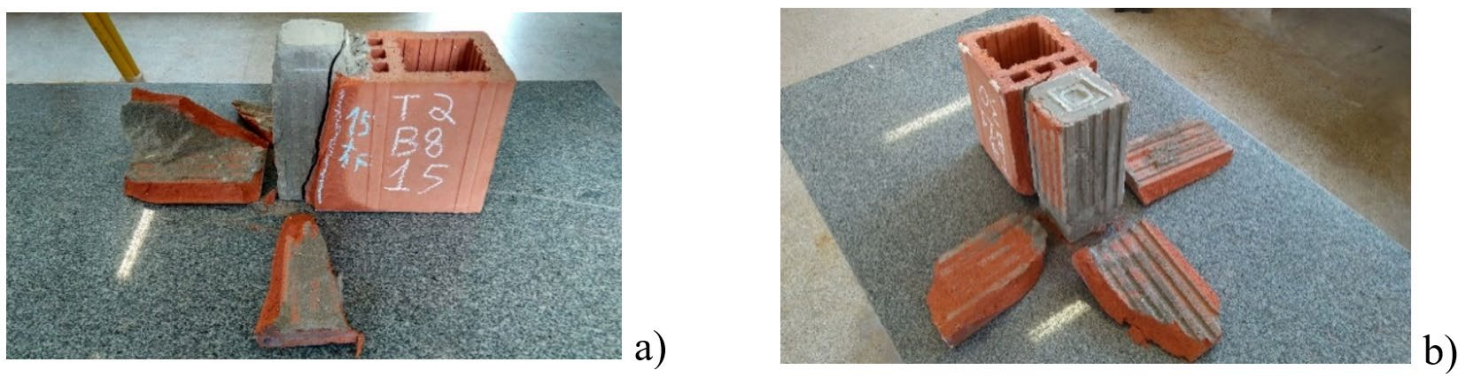

Figure 9. BM16 specimens after push-out test.

The BM16 specimens after push-out test are shown in Figure 9a for the use of G15 grout and in Figure $9 \mathrm{~b}$ for G30 grout. As can be seen, the use of grout G15 presented rupture of both block and grout, and the use of grout G30 produced the rupture of the block with little damage to the grout. The BM4 specimens after pushout test are shown in Figure 10a for the use of G15 grout and in Figure 10b for G30 grout. As can be seen the use of grout G15 produced rupture of the block and the use of grout G30 produced the slippage of the grout.

The BV0 specimens after push-out test are shown in Figure 11a for the use of G15 grout and in Figure $11 \mathrm{~b}$ for G30 grout. As can be seen the use of grout G15 produced rupture of both block and gout, and the use of grout G30 produced the rupture of the block with little damage to the grout. The BV10 specimens after pushout test are shown in Figure 12a for the use of G15 grout and in Figure 12b for G30 grout. As can be seen the use of grout G15 produced rupture of both block and gout, and the use of grout G30 produced the rupture of the block with less damage to the grout. The influence of the block type on the push-out test may vary on account of the grout used. Thus, variance analysis of a single factor (the type of block) was performed for each type of grout, considering a $95 \%$ confidence level. The results showed that the type of block significantly influenced the results with both types of grouts. For G15, approximately $67 \%$ of the results of bond strength can be explained by the type of block. For the use of G30, approximately $90 \%$ of the bond strength results can 
be explained by the block type. Therefore, the type of block has a greater influence on the results of bond strength obtained with the $30 \mathrm{MPa}$ grout.
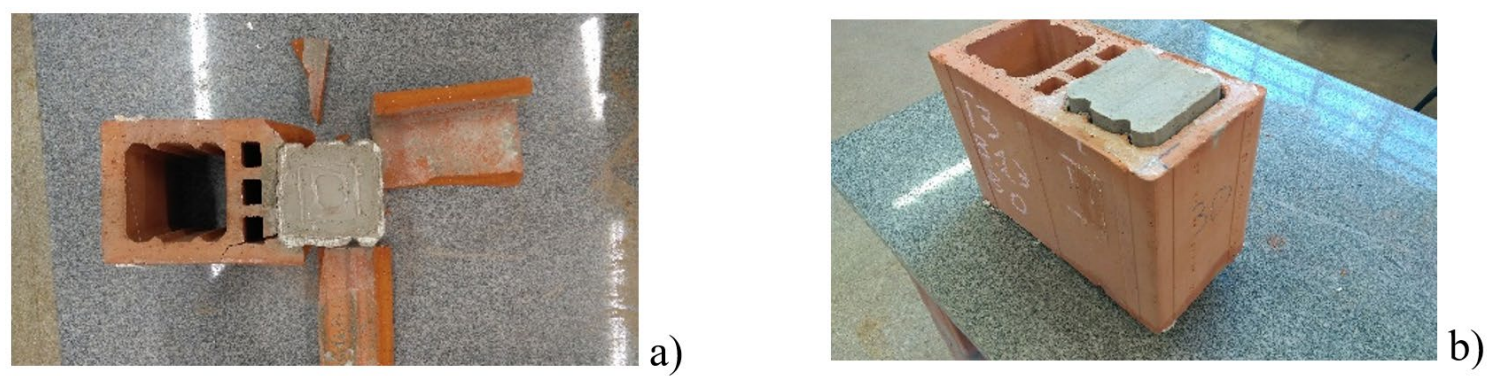

Figure 10. BM4 specimens after push-out test.
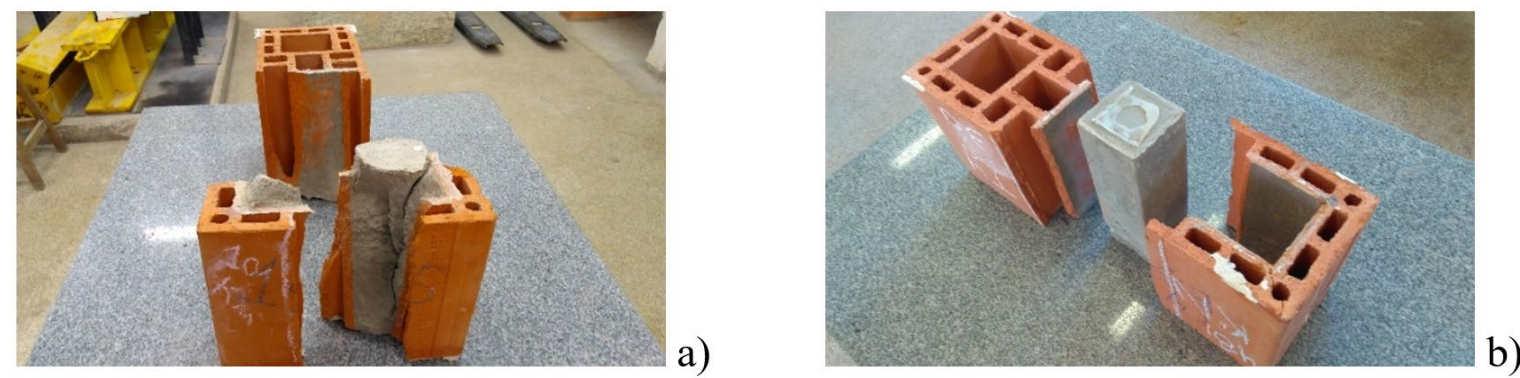

Figure 11. BV0 specimens after push-out test.
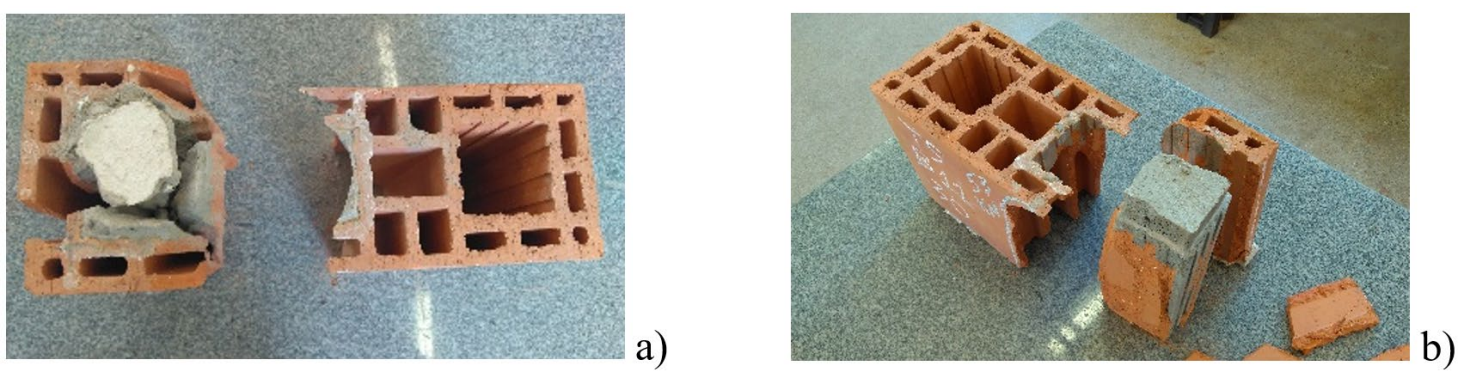

Figure 12. BV10 specimens after push-out test.

To compare the bond strength provided by each type of block, the Tukey test was performed. The results of these tests are shown in Figure 13a and Figure 13b, respectively, for the use of grout G15 and G30. As can be seen in Figure 13, the red lines indicate that the results of these two types of blocks were significantly different from each other. The black lines indicate that the results were not significantly different. BM16 and BV10 were the only types of blocks that did not presented significant differences in the push-out results for both types of grouts. In Figure $12 \mathrm{~b}$ there is a greater number of results indicating significant differences between blocks. Therefore, the bond strength was more influenced by the type of block for the use of grout G30. 


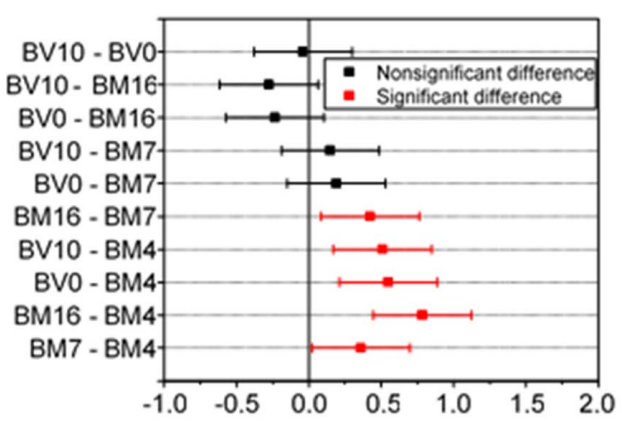

a)

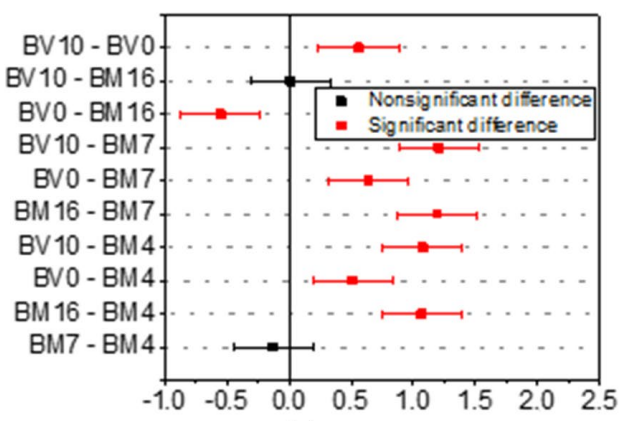

b)

Figure 13. Tukey test for the push-out results (mean comparison).

\subsection{Third phase - Pull-out test}

To complement the evaluation of the adherence, pull-out tests were carried out, for the block types BM7, BM16, and BV10. The mean ultimate stress obtained in the pull-out test for each one of these three types of blocks with both grout types are presented in Table 5. The compressive strength of mortar was tested according to NBR 13279 [21], with results equal to $11.6 \mathrm{MPa}$ and $18.2 \mathrm{MPa}$, at 28 days. The first mortar was used with BV10, and the second with BM7 and BM16. The reinforcement tension properties were obtained by direct tension test, performed in three specimens according to the procedure described in NBR ISO 6892-1 [22]. The mean ultimate stress of the reinforcement was 689.1 $\mathrm{MPa}$ and the mean yield stress was 555.8 MPa. The mode of rupture observed did not show the slippage of the grout, but slippage of the rebar. This usually occurred after the rebar has reached its yield stress and some damage (cracks) to the walls has occurred. With blocks BM7 and BV10, and G15, the reinforcement bar reached 95\% of its yield strength. All G30 and all BM16-specimens allowed the reinforcement to yield. All specimens not presented slippage of the grout. From these observations it is possible to admit that the three types of blocks can promote adequate bond strength with the grouts, with BM16 allowing a better bond.

Table 5. Pull-out results.

\begin{tabular}{cccccc} 
Type of block & Type of grout & $\begin{array}{c}\text { Mean ultimate } \\
\text { load (kN) }\end{array}$ & $\begin{array}{c}\text { Mean ultimate } \\
\text { stress (MPa) }\end{array}$ & S. D. (MPa) & C. V. (\%) \\
\hline \multirow{2}{*}{ BM7 } & G15 & 121.9 & 610.0 & 64.2 & 10.5 \\
\cline { 2 - 6 } & G30* & 105.4 & $\left.527.0^{(* *}\right)$ & 42.1 & 5.0 \\
\hline \multirow{2}{*}{ BM16 } & G15 & 123.8 & 619.0 & 32.6 & 6.3 \\
& G30 & 114.4 & 572.1 & 39.6 & 3.4 \\
\hline
\end{tabular}

$(*)$ One specimen was not considered because the bar slipped at a lower load. $(* *)$ Ultimate load smaller than the reinforcement yield strength

Table 5 shows that, for the same type of block, the highest values of tensile strength were obtained for the samples filled with G15 comparing to G30. This behavior occurred for the three types of blocks tested. This same behavior was also identified in the push-out tests, where the same type of block showed higher bond strength with G15 than with G30. The pull-out results with G15 as compared with G30 were approximately 14,8 and $8 \%$ higher, respectively, for blocks BM7, BM16, and BV10. The difference obtained in the pull-out test for a block type when using G15 and G30 was smaller than the differences observed for the same block type on the push-out test. This reduced difference between the pull-out results may indicate that other factors than the bond strength between block and grout influenced the pullout results. It is possible that the misalignment of the courses in a wall and the variation in the position of the indentations in BM7, between one course and the next, may have contributed to these results.

In the push-out test (second phase), the results obtained with block type BV10 were superior to those obtained with BM7, for both types of grouts. However, in the case of the pull-out tests the results obtained for BV10 and BM7 types of blocks became similar. This result reinforces the possibility of the existence of factors, other than the bond strength between the materials, that influences the pull-out results. It is likely that the distinct geometry of the block type BM7, 
which makes it possible to position the indentations between the blocks in one course different than that of the blocks in another course, may have contributed to the increased tension in the steel during the pull-out test. To check whether the type of block or type of grout had a significant influence on the mean ultimate load obtained in the pull-out test, analysis of variance (ANOVA) was performed taking two factors in consideration and a 95\% confidence level. The results indicated that the type of block $\left(\mathrm{R}^{2} \cong 10 \%\right)$ does not have a significant influence on the stress observed in the pull-out test. However, the type of grout $\left(\mathrm{R}^{2} \cong 45 \%\right)$ can influence the results. The iteration between the types of blocks and grout $\left(\mathrm{R}^{2} \cong 4 \%\right)$, does not significantly influence the results.

\subsection{Fourth phase - Grout Shrinkage}

As the grout showed some signs of shrinkage in some specimens used in the push-out test, it was necessary to investigate this material's properties. The results of dimensional variation made with grout prisms indicate a greater shrinkage in grout G30 $(0.96 \mathrm{~mm} / \mathrm{m})$ compared to grout $\mathrm{G} 15(0.66 \mathrm{~mm} / \mathrm{m})$, after 28 days of curing. The length reduction (shrinkage) observed for grout G15 was approximately 31\% inferior to that observed for grout G30. These results were obtained according to the procedure described in NBR 15261 [23] code. The water/grout (anhydrous) ratio used to obtain the desired consistency at this phase was approximately 0.14 and 0.19 , respectively, for G15 and G30. If shrinkage cracks are formed in the core of the grout, it can adversely affect its mechanical properties, and if cracks are formed in the interface between blocks and grout it can reduce the contact area between the materials, impairing their adherence. To evaluate the effects of the shrinkage inside the blocks, specimens were cut in half and the amount of cracks were measured. The percentage of the length of cracks formed, inside the grout or in the block-grout interface, in relation to the perimeter of the hole in each type of block are presented in Table 6 . Based on the amount of cracks formed at interface block/grout it is possible to estimate the loss in the contact area between these materials, as can be seen in column 4 of Table 6 .

Table 6. Percentual of cracks formed.

\begin{tabular}{ccccc}
\hline Block type & Grout type & Cracks in the grout & $\begin{array}{c}\text { Cracks on the interface } \\
\text { (Lost on the contact area) }\end{array}$ & Total cracks \\
\hline \multirow{2}{*}{ BM4 } & G15 & $40.0 \%$ & $9.0 \%$ & $49.0 \%$ \\
& $\mathrm{G} 30$ & $8.8 \%$ & $62.0 \%$ & $70.8 \%$ \\
\hline \multirow{2}{*}{ BM7 } & $\mathrm{G} 15$ & $36.3 \%$ & $7.7 \%$ & $44.0 \%$ \\
& $\mathrm{G} 30$ & $21.6 \%$ & $37.8 \%$ & $59.2 \%$ \\
\hline \multirow{2}{*}{ BM16 } & $\mathrm{G} 15$ & $31.4 \%$ & $0.0 \%$ & $31.4 \%$ \\
\hline \multirow{2}{*}{ BV0 } & $\mathrm{G} 30$ & $12.4 \%$ & $20.9 \%$ & $33.2 \%$ \\
\hline \multirow{2}{*}{$\mathrm{BV} 10$} & $\mathrm{G} 15$ & $41.6 \%$ & $0.0 \%$ & $41.6 \%$ \\
\hline & $\mathrm{G} 30$ & $17.8 \%$ & $42.2 \%$ & $60.0 \%$ \\
\hline & $\mathrm{G} 15$ & $31.0 \%$ & $0.0 \%$ & $31.0 \%$ \\
\hline
\end{tabular}

As can be seen in Table 6, for the same type of block, there was an increase in the percentage length of cracks formed at the block-grout interface and in total cracks, when using the grout with higher compressive strength (G30). In the case of the length of the cracks formed inside the grout, the opposite occurred, meaning that the grout with lower compressive strength (G15) presented a higher percentage of cracks, for the same type of block. The increase in the length of cracks formed at the block-grout interface for samples with $30 \mathrm{MPa}$ grout may be one of the reasons for its lower performance in the push-out and pull-out tests. For both tests a better performance was observed with the use of grout $15 \mathrm{MPa}$. Kingsley et al [1] suggests that increasing the amount of water used in the mixture of grout will result in greater shrinkage. The results obtained in this research seems to agree with the authors observations, since the amount of cracks formed while using the grout G30 that consumed more water int mixture than G15, was greater. With the formation of a greater number of cracks at the interface between block and grout, the effective contact area between the materials was reduced. Thus, it is possible that the portion of material which was in contact resisting the load applied during the test was reduced, causing the lower results. 


\section{LOAD ESTIMATION IN THE PUSH-OUT TEST}

This experimental program helped identify two factors that could affect the bond between clay blocks and grouts: the shrinkage of the filling material and the geometric shape of the cells of the blocks. These two factors produce changes in the real contact area presented by a particular type of block and grout. The contact area presented by a certain type of block can be larger or smaller, depending on the overall dimension of the cell and the presence of indentations inside the cells. The shrinkage of the grout can cause a reduction in the effective contact area between grout and block. Based on this information, it becomes possible to use coefficients that incorporate the changes caused in the contact area due the shrinkage of the grout and the geometry of the cells of the blocks, in the estimation of the maximum load supported by each type of block and grout during the push-out tests. To predict the maximum load resisted by each combination of block type and grout type, it is necessary to use a previously defined bond strength as a reference, and, to use two factors, namely:

- A geometric factor to represent the increase in the contact area promoted by the presence of indentations or grooves, inside of a cell (k1); and,

- The effects of the loss of contact area due to the shrinkage of the grout $(\mathrm{k} 2)$.

The reference bond strength chosen for this estimate was provided by the combination of block type BV0 and grout type G15. This combination was chosen because this block type is the only one with a smooth surface inside the block's cell and this grout did not show any signs of shrinkage inside this block type. Two types of blocks that have the same length of cell-perimeter, may present different cross-sectional areas in the cell. These areas may be small if the number of indentations inside the cell are large. If the number of indentations inside the cell is small, the cross-section of the cell may be larger. Therefore, it is possible to estimate the influence of the presence of the indentations by comparing the cross-sectional area of a cell in a certain type of block with an assumed cross-sectional area, such as a square and smooth cross-section which has the same perimeter as the block that is being evaluated. Equation 3 and Equation 4 were used for calculating the fictitious contact area:

$\mathrm{P}=\frac{C \cdot A}{H}$

$$
F . A .=\left(\frac{P}{4}\right)^{2}
$$

where $P=$ perimeter of the block's cell $\left(\mathrm{cm}^{2}\right) ; C . A .=$ contact area presented for this type of block $\left(\mathrm{cm}^{2}\right) ; H=$ nominal height of the block $(19 \mathrm{~cm})$; and $F . A$. = fictitious cross-sectional area $\left(\mathrm{cm}^{2}\right)$, assumed to be a square with a smooth surface.

Based on the real and fictitious values of the cross-sectional area presented by the cell of each type of block, it is possible to calculate the geometric coefficient k1, using the Equation 5:

$k 1=\frac{F \cdot A .}{\operatorname{Cros} \cdot A}$

where $K 1=$ geometric coefficient of the block's cell (dimensionless); F.A. = fictitious cross-sectional area $\left(\mathrm{cm}^{2}\right)$; and Cros.A. $=$ real cross-sectional area of the cell $\left(\mathrm{cm}^{2}\right)$.

The coefficient $\mathrm{k} 2$ represents the value of the contact area lost by the shrinkage of the grout inside each type of block. This factor can be calculated using the Equation 6 and Equation 7 below:

R.C.A. $=\left(\right.$ A.C. $\left.-\frac{A . C . \times P . L . C}{100}\right)$

$k 2=\frac{A \cdot C \cdot R}{A \cdot C .}$

Where R.C.A. = remaining contact area after shrinkage $\left(\mathrm{cm}^{2}\right) ; A . C .=$ average contact area of the blocks used on the push-out test $\left(\mathrm{cm}^{2}\right) ;$ P.L.C. $=$ percentage value of loss of contact area due to shrinkage (\%); and $K 2=$ shrinkage coefficient (dimensionless).

The $\mathrm{k} 1$ factor represents the increase in the contact area of the blocks caused by the presence of indentations and grooves. However, the increase in the contact area can also be caused by the increase of the cell's overall dimensions. 
Therefore, to consider this influence for estimating the load for each type of block and grout, the smooth contact area presented by each type of block must be considered. The smooth contact area was presented in Table 1 . Now, with the use of the reference bond strength, the smooth contact area of each type of block and the factors $\mathrm{k} 1$ and $\mathrm{k} 2$, it is possible to estimate the maximum force necessary for each combination of block type and grout for the push-out test, using of the equation 8 below:

$Q$ máx. $=\frac{R \cdot A . S . \times S \cdot C \cdot A \times k 1 \times k 2}{10}$

Where $Q m a ́ x=$ maximum theoretical force estimated for each combination of block and grout $(\mathrm{kN})$; R.A.S. $=$ reference bond strength (MPa); A.C. $=$ average contact area of the blocks used on the push-out test $\left(\mathrm{cm}^{2}\right) ; \mathrm{S}$.C.A. $=$ smooth contact area of each type of block, ignoring the increments in the area caused by the indentations $\left(\mathrm{cm}^{2}\right) ; K 1=$ geometric coefficient of the block's cell (dimensionless); and $K 2=$ shrinkage coefficient (dimensionless). The maximum theoretical forces obtained by using the Equation 8 are shown in Table 7.

Table 7. Maximum theoretical force.

\begin{tabular}{|c|c|c|c|c|c|c|}
\hline $\begin{array}{l}\text { Type of } \\
\text { block }\end{array}$ & $\begin{array}{c}\text { Type of } \\
\text { grout }\end{array}$ & k1 & k2 & $\begin{array}{c}\text { Smooth contact area } \\
\left(\mathrm{cm}^{2}\right)\end{array}$ & Bond strength (MPa) & $\begin{array}{c}\text { Maximum theoretical } \\
\text { force }(\mathrm{kN})\end{array}$ \\
\hline \multirow{2}{*}{ BM4 } & G15 & 0.99 & 0.9 & 688 & 1.56 & 96.6 \\
\hline & G30 & 0.99 & 0.33 & 688 & 1.56 & 40.2 \\
\hline \multirow{2}{*}{ BM7 } & G15 & 0.96 & 0.92 & 652 & 1.56 & 89.7 \\
\hline & G30 & 0.95 & 0.59 & 652 & 1.56 & 59.9 \\
\hline \multirow{2}{*}{ BM16 } & G15 & 1.52 & 1 & 737 & 1.56 & 174.9 \\
\hline & G30 & 1.52 & 0.72 & 737 & 1.56 & 138.3 \\
\hline \multirow{2}{*}{ BV0 } & G15 & 0.97 & 1 & 547 & 1.56 & 83.1 \\
\hline & G30 & 0.98 & 0.58 & 547 & 1.56 & 48.4 \\
\hline \multirow{2}{*}{ BV10 } & G15 & 1.56 & 1 & 561 & 1.56 & 136.3 \\
\hline & G30 & 1.56 & 0.9 & 561 & 1.56 & 124.6 \\
\hline
\end{tabular}

Figure 14 shows a graphical comparison of the theoretical and experimental results for each type of block and grout. As can be seen, there are some results in which the theoretical values are very close to the experimental ones. However, in other cases theoretical and experimental results differ considerably, as for the block type BM7 and grout G30. The large coefficient of variation observed in some of the push-out tests and the small number of samples used to determine the grout shrinkage percentage may have contributed to the larger differences. The correlation coefficient $\left(\mathrm{R}^{2}\right)$ between theoretical and experimental data was 0.86 . Meaning that the theoretical results can represent $86 \%$ of the experimental ones. Which is a good degree of approximation. When separating the results for each type of grout, the correlation coefficient is equal to 0.77 for grout G15 and 0.87 for grout G30. Thus, the results indicate that it is possible to use the two coefficients mentioned here to estimate the maximum load obtained with each combination of block and grout on the push-out test. It will be necessary, however, to conduct more studies to improve this estimation and investigate another factor that can interfere in this behavior.

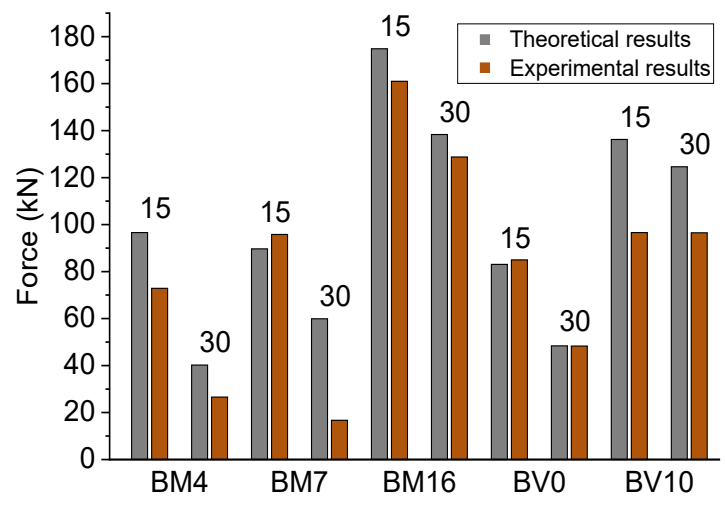

Figure 14. Comparison between theoretical and experimental results. 


\section{CONCLUSIONS}

The objective of this article was to evaluate the adherence between five different types of fired clay blocks and two types of grouts. Push-out and pull-out tests were performed to assess the adherence among the different combinations of blocks and grouts.

There are many factors that can influence the performance of the adherence presented by the contact interface of blocks and grouts. One of these factors is the geometry of the cells of the blocks that can increase the bond strength by providing a higher contact area. This increase in the contact area can be reached by a grooved internal surface and a greater number of indentations inside the cells. Other factor that can influence the bond strength is the properties of the grout used. In the case of this research, the highest values of adherence were obtained while utilizing the grout G15 in relation to the grout G30, for the same type of block. Specimens constructed with G15 grout provided higher values of adherence in the Pushout and in the Pull-out tests. One of possible the explanations is the fact that the shrinkage presented by the grout G30 was higher than that presented by the grout G15, reducing the contact surface of block and grout.

The shrinkage of the grout and the geometry of the cell of the block can be used to estimate the bond strength between the clay blocks and grouts on the Push-out tests. The equation developed using factors $\mathrm{k} 1$ and $\mathrm{k} 2$ to compensate these factors shown to be effective to obtain theoretical results similar to the experimental ones, with good correlation. The test procedure developed to estimate the percentage of contact area lost due to grouts shrinkage shows to be promising, since its results were used in the equation to estimate the bond strength between blocks and grouts and shown good correlation. However, more study must be done because there are other variables that can affect the results. These results show that it is possible to use different characteristics of blocks and grouts to increase the adherence between these materials and provide a better behavior for reinforced masonry structures. However, it looks like if block types with a grooved hollow cell are used, a bigger contact surface is produced, and a higher bond strength appears to be assured.

\section{ACKNOWLEDGEMENTS}

This study was financed by the Associação Nacional da Indústria Cerâmica (ANICER) and by the Coordenação de Aperfeiçoamento de Pessoal de Nível Superior - Brasil (CAPES) - Finance Code 001.

\section{REFERENCES}

[1] G. R. Kingsley, L. G. Tulin, and J. L. Noland (1985). Parameters influencing the quality of grout in hollow clay masonry. In 7th Int. Brick and Block Masonry Conf. (IBMAC), Melbourne, Fev. 1985, pp. 1085-1091.

[2] Z. Soric and L. G. Tulin. Bond in reinforced concrete masonry. In: 4th North American Masonry Conf., Los Angeles, California, 1987, p. 47.1-47.16.

[3] K. Ahmed and L. R. Feldman. Evaluation of contact and noncontact lap splices in concrete block masonry construction, Canadian J. Civil Eng., vol. 39, n. 515-525, 2012.

[4] A. Kisin (2014). "Evaluation of mitigative techniques for non-contact lap splices in concrete block construction," Ph.D. dissertation, Dept. Civil and Geological Eng., Univ. Saskatchewan, Saskatoon, Canada. 201 p.

[5] O. S. Izquierdo, M. R. S. Corrêa and I. I. Soto, Study of the block/grout interface in concrete and clay block masonry structures," Rev. IBRACON Estrut. Mater., vol. 10, n. 4, pp. 924-936, Ago. 2017. http://dx.doi.org/10.1590/s1983-41952017000400009.

[6] J. A. Thamboo, M. Dhanasekar and C. Yan, "Flexural and shear bond characteristics of thin layer polymer cement mortared concrete masonry," Construction and Building Mater., vol. 46, pp. 104-113, Set. 2013. http://dx.doi.org/10.1016/j.conbuildmat.2013.04.002.

[7] L. A. Pereira de Oliveira, "Resistência de aderência como parâmetro de compatibilidade entre o graute de enchimentos e as unidades da alvenaria estrutural," in 5th Inter. Seminar on Structural Masonry for Develop. Countries, Florianópolis, SC, Brasil, 1994, pp. $214-227$.

[8] L. A. Pereira de Oliveira, "The micro-concrete infill strength's influence on the compressive masonry strength," in European Ready Mix Org. Congr. - ERMCO 98, Lisboa, Portugal, 1998, pp. 691-700.

[9] L. Guarnieri, C. P. Bergmann and Filho, L. C. P. S. "Influência da aderência graute/bloco cerâmico estrutural na resistência mecânica do conjunto," in XIII Congr. Inter. sobre Patologia e Reabilitação de Estruturas (13 CINPAR). Crato, CE, Brazil, 2017.

[10] O. S. Izquierdo, “Estudo da interface bloco/graute em elementos de alvenaria estrutural,” Ph.D. dissertation, Univ. São Paulo, São Carlos, SP, Brasil, 2015. 322 p.

[11] D.T. Biggs, "Grouting masonry using Portland cement-lime mortars," in Int. Building Lime Symp., Orlando, FL, USA, 2005 p. $2-15$.

[12] American Society for Testing and Materials, Standard Specification for Grout for Masonry, ASTM C476, 2020.

[13] Z. Soric and L.G. Tulin, "Bond Stress/Deformation in Pull-Out Masonry Specimens," J. Struct. Eng., vol. 115, no. 10, pp. 25882602, 1989., http://dx.doi.org/10.1061/ (ASCE)0733-9445(1989)115:10(2588). 
[14] Associação Brasileira de Normas Técnicas, Componentes cerâmicos - Blocos e tijolos para alvenaria Parte 2: Métodos de ensaios, NBR 15270-2, 2017.

[15] Associação Brasileira de Normas Técnicas, Concreto - ensaios de compressão de corpos de prova cilíndricos, NBR $5739,2018$.

[16] Associação Brasileira de Normas Técnicas, Concreto e argamassa - Determinação da resistência à tração por compressão diametral de corpos de prova cilíndricos, NBR 7222, 2011.

[17] Associação Brasileira de Normas Técnicas, Concreto - Determinação do módulo estático de elasticidade à compressão, NBR $8522,2008$.

[18] Associação Brasileira de Normas Técnicas, Argamassa e concreto endurecidos - Determinação da absorção de água, índice de vazios e massa especifica, NBR 9778, 2005.

[19] Associação Brasileira de Normas Técnicas, Alvenaria estrutural-Parte 1: Projeto, NBR 16868-1, 2020.

[20] Associação Brasileira de Normas Técnicas, Projeto de estruturas de concreto - Procedimento, NBR 6118, 2014.

[21] Associação Brasileira de Normas Técnicas, Argamassa para assentamento e revestimento de paredes e tetos - Determinação da resistência à tração na flexão e à compressão, NBR 13279, 2005.

[22] Associação Brasileira de Normas Técnicas, Materiais metálicos - Ensaio de Tração Parte 1: Método de ensaio à temperatura ambiente, NBR ISO 6892-1, 2013.

[23] Associação Brasileira de Normas Técnicas, Argamassa para assentamento e revestimento de paredes e tetos - Determinação da variação dimensional (retratação ou expansão linear), NBR 15261, 2005.

Author contributions: GS: conceptualization, testing, formal analyses, writing; GAP: conceptualization, formal analyses, writing, funding acquisition, supervision.

Editors: Fernando S. Fonseca 